\title{
Spontaneous periorbital ecchymosis: a rare presentation of acute lymphoblastic leukaemia
}

\author{
Aditya Jandial, Kundan Mishra, Alka Khadwal, Pankaj Malhotra
}

Department of Medicine, Postgraduate Institute of Medical Education and Research, Chandigarh, India

\section{Correspondence to} Dr Kundan Mishra, mishrak20@rediffmail.com

Accepted 6 March 2018

\section{DESCRIPTION}

A 45-year-old woman presented with spontaneous discolouration around the left eye for 1 week. She also gave a history of easy fatigability for 1 month. There was no history of any preceding injury in the head and neck area. She denied any headache, vomiting or visual disturbances. Examination showed hepatosplenomegaly and ecchymosis around the left eye (raccoon eye), along with subconjunctival haemorrhage (figure 1A). Her fundus examination was unremarkable. Her haemoglobin was $138 \mathrm{~g} / \mathrm{L}$, white blood cell count was $51 \times 10^{9} / \mathrm{L}$ and platelet was $19 \times 10^{9} / \mathrm{L}$. Her peripheral blood smear had 24\% blast with CD34, CD10 and CD19 positivity on flow cytometry, confirming a diagnosis of acute lymphoblastic leukaemia. A biopsy from the periorbital area could not be done due to denial of consent from the patient. She was managed with chemotherapy and transfusion support. She showed gradual improvement in periorbital ecchymosis and took 2 weeks to resolve (figure 1B).

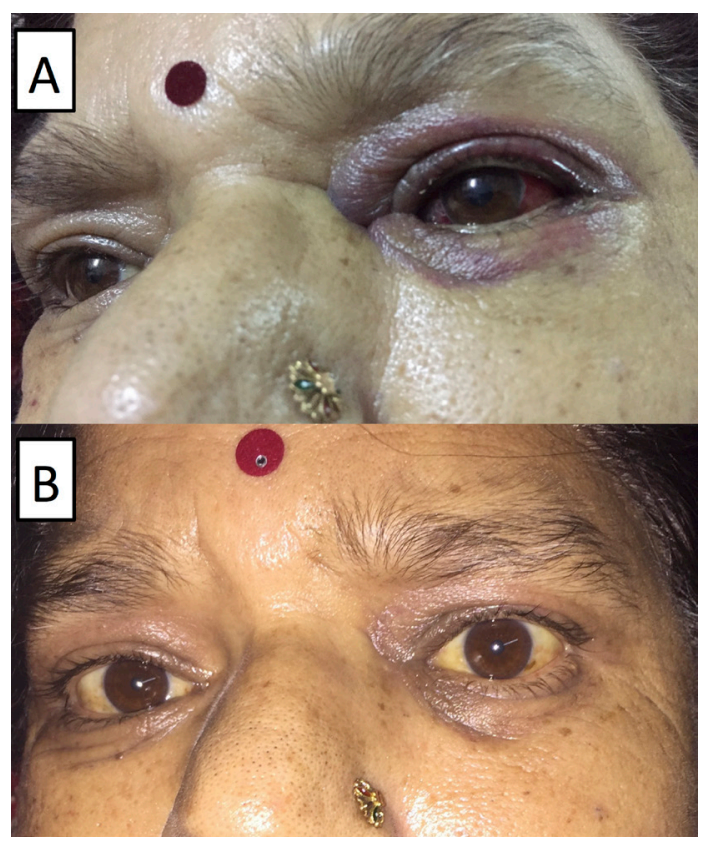

To cite: Jandial $A$, Mishra $K$, Khadwal A, et al. BMJ Case Rep Published Online First: [please include Day Month Year]. doi:10.1136/bcr-2018224228
Figure 1 Clinical photograph of the patient showing periorbital ecchymosis, typical of raccoon eye and associated subconjunctival haemorrhage (A). Resolution of ecchymosis following chemotherapy (B).
Periorbital ecchymosis or raccoon eye or panda sign is commonly seen in surgical emergency and results from accidental injuries to the base of the skull. It is a useful clinical sign that demands urgency in further evaluation and correlates well with the radiological sign of base of skull fracture. ${ }^{1}$ However, trivial injury-induced or non-accidental or spontaneous raccoon eye can develop in a variety of medical conditions like migraine, amyloidosis, multiple myeloma, acute leukaemia and neuroblastoma. ${ }^{2}$ Spontaneous periorbital ecchymosis results due to fragile capillaries or coagulopathy, however can also be a feature of a metastatic disease. ${ }^{3}$ The unilateral raccoon eye in a systemic disease has been reported before, but the cause remains elusive. The possible hypothesis to explain this rare finding includes trivial trauma (unilateral, unnoticed) and anatomical variation. The treatment is directed at the underlying aetiology, which is unfolded by history, clinical examination and investigation.

\section{Learning points}

Periorbital ecchymosis (raccoon eye or panda sign) is a common clinical sign of skull base injury resulting from accidental injuries.

- Spontaneous periorbital ecchymosis harbingers a variety of medical disorders.

- An urgent clinical evaluation is compulsory, which unfolds the underlying disease.

Contributors $\mathrm{KM}, \mathrm{AJ}, \mathrm{AK}$ and $\mathrm{PM}$ contributed to the management of the patient. KM and AJ prepared the manuscript, which was read and accepted by all the authors.

Funding This research received no specific grant from any funding agency in the public, commercial or not-for-profit sectors.

Competing interests None declared.

Patient consent Obtained.

Provenance and peer review Not commissioned; externally peer reviewed.

(C) BMJ Publishing Group Ltd (unless otherwise stated in the text of the article) 2018. All rights reserved. No commercial use is permitted unless otherwise expressly granted.

\section{REFERENCES}

1 McPheeters RA, White S, Winter A. Raccoon eyes. West J Emerg Med 2010;11:97.

2 Cheng FW, Ho AC, Li CK. Raccoon eyes as presentation of lymphoblastic lymphoma in a child. Br J Haematol 2013;162:2.

3 Inokuchi R, Tagami S, Maehara H. An elderly woman with bilateral raccoon eyes. Emerg Med J 2016;33:781. 
Copyright 2018 BMJ Publishing Group. All rights reserved. For permission to reuse any of this content visit http://group.bmj.com/group/rights-licensing/permissions.

BMJ Case Report Fellows may re-use this article for personal use and teaching without any further permission.

Become a Fellow of BMJ Case Reports today and you can:

- Submit as many cases as you like

- Enjoy fast sympathetic peer review and rapid publication of accepted articles

Access all the published articles

- Re-use any of the published material for personal use and teaching without further permission

For information on Institutional Fellowships contact consortiasales@bmjgroup.com

Visit casereports.bmj.com for more articles like this and to become a Fellow 